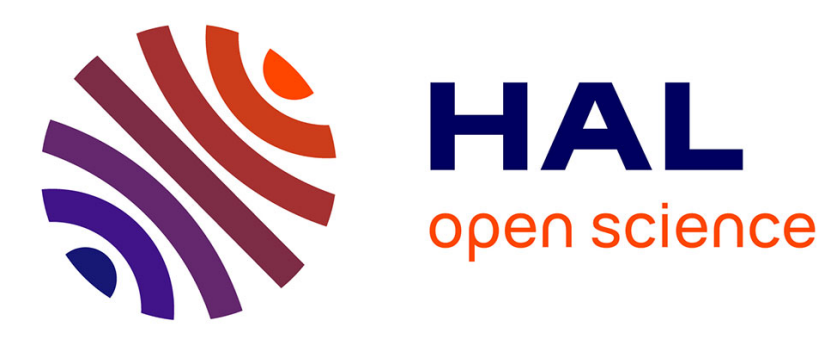

\title{
High Energy Ferrite Magnets
}

\author{
H. Taguchi, T. Takeishi, K. Suwa, K. Masuzawa, Y. Minachi
}

\section{To cite this version:}

H. Taguchi, T. Takeishi, K. Suwa, K. Masuzawa, Y. Minachi. High Energy Ferrite Magnets. Journal de Physique IV Proceedings, 1997, 07 (C1), pp.C1-311-C1-312. 10.1051/jp4:19971122 . jpa-00254763

\section{HAL Id: jpa-00254763 https://hal.science/jpa-00254763}

Submitted on 1 Jan 1997

HAL is a multi-disciplinary open access archive for the deposit and dissemination of scientific research documents, whether they are published or not. The documents may come from teaching and research institutions in France or abroad, or from public or private research centers.
L'archive ouverte pluridisciplinaire HAL, est destinée au dépôt et à la diffusion de documents scientifiques de niveau recherche, publiés ou non, émanant des établissements d'enseignement et de recherche français ou étrangers, des laboratoires publics ou privés. 


\title{
High Energy Ferrite Magnets
}

\author{
H. Taguchi, T. Takeishi, K. Suwa, K. Masuzawa and Y. Minachi \\ TDK Materials Research Center, 570-2 Matugashita, Minamihatori, Narita, Chiba 286, Japan
}

\begin{abstract}
Lanthanum and zinc substitution in M-type hexaferrite was studied in detail in order to increase the saturation magnetization. For the composition $\mathrm{Sr}_{07} \mathrm{La}_{03} \mathrm{Fe}_{11.7} \mathrm{Zn}_{0.3} \mathrm{O}_{19}$, the saturation magnetization was increased by more than $4 \%$ and the uniaxial anisotropy constant $\left(\mathrm{K}_{1}\right)$ was almost the same as that of non-substituted Ba-ferrite. Furthermore, high energy ferrite magnets having more than $40 \mathrm{~kJ} / \mathrm{m}^{3}(5 \mathrm{MGOc})$ were obtained for the first time by the new process for high orientation, high density and submicron-sized grains.
\end{abstract}

\section{INTRODUCTION}

M-type ferrite magnets are widely used throughout the world. The practical limit of flux density (Br) and maximum energy product $\left((\mathrm{BH})_{\max }\right)$ are around $0.44 \mathrm{~T}(4.4 \mathrm{kG})$ and $37 \mathrm{~kJ} / \mathrm{m}^{3}(4.7 \mathrm{MGOe})$, respectively. Despite numerous studies concerning cation substitution in the $\mathbf{M}$-structure, very few attempts have proved successful improving their fundamental properties. According to Gorter [1], one can expect that saturation magnetization will increase when non-magnetic ions such as $\mathrm{Zn}$ occupy tetrahedral $4 f 1$ sites in the $M$-structure, as is true in spinel ferrite. This is because $\mathrm{Fe}^{3+}$ at the $4 \mathrm{f} 1$ sites have a down-spin and $\mathrm{Zn}{ }^{2+}$ have a strong tetrahedral-site-preference. A Lanthanoid substitution for strontium $\left(\mathrm{R}^{3+}\right.$ or $\mathrm{R}^{4+} \rightarrow \mathrm{Sr}^{2+}$ ) is one way to compensate for the decrease in positive charge $\left(\mathrm{Zn}^{2+} \rightarrow \mathrm{Fe}^{3+}\right)$. Among the Lanthanoids, $\mathrm{La}^{3+}$ has the largest solubility limit in M-type ferrite [2]. The formula of $\mathrm{Ba}_{1-x} \mathrm{La}_{x} \mathrm{Fe}_{12-x} \mathrm{M}_{\mathrm{x}} \mathrm{O}_{19}(\mathrm{M}=\mathrm{Zn}$ or $\mathrm{Mg})$ was first made public in 1958 [3]. Compounds with the basic formula $\mathrm{LaM}^{2+} \mathrm{Fe}_{11} \mathrm{O}_{19}(\mathrm{M}=\mathrm{Cu}, \mathrm{Cd}, \mathrm{Zn}, \mathrm{Ni}$, Co or $\mathrm{Mg})$ were studied in 1970 [4]. Taking into consideration these references, the possibility of using $\mathrm{Sr}_{1-\mathrm{x}} \mathrm{La}_{\mathrm{x}} \mathrm{Fe}_{12-\mathrm{x}} \mathrm{Zn}_{\mathrm{x}} \mathrm{O}_{19}$ compounds as permanent magnets was investigated.

\section{EXPERIMENTAL PROCEDURE}

Mixtures of $\mathrm{Fe} 2 \mathrm{O} 3, \mathrm{SrCO}, \mathrm{ZnO}$ and $\mathrm{La2O} 3$ were attrition-milled in water and calcined at $1150 \sim 1250^{\circ} \mathrm{C}$ in air, followed by drying and granulating. The powder calcined at $1200^{\circ} \mathrm{C}$ was first pulverized using a dry vibratory rod-mill with $\mathrm{SiO} 2$ and $\mathrm{CaCO} 3$, then ball-milled in xylene with oleic acid. After adjusting the slurry content, pellets of $30 \phi \times 15 \mathrm{~mm} h$ were wetpressed while applying a magnetic field of up to $12 \mathrm{kOe}$ in the thickness direction. This newly developed wet-process using organic solvent (xylene) and surfactant (oleic acid) is very effective in acheiving high orientation for submicron-sized particles under a magnetic field [5]. The wet-pressed pellets were sintered at $1180 \sim 1240^{\circ} \mathrm{C}$ in air. $I-H$ hysteresis curves were measured using a $30 \mathrm{~mm} \phi$ search coil in a field of up to $25 \mathrm{kOe}$. $\sigma-\mathrm{T}$ curves were measured using a VSM. K1 values were measured using a torque magneto-meter after grinding to cylindrical shapes of $5 \phi \times 2 \mathrm{~mm} h$ (a-axis and c-axis were both in the radial plane). $\mathrm{HA}_{\mathrm{A}}$ was calculated using the formula $\mathrm{HA}=2 \mathrm{~K} 1 / \mathrm{Is}$. Mossbauer spectra were taken and compared with published data for M-type ferrite. Micro- and nano-structure was investigated by SEM and TEM-EDS.

\section{RESULTS AND DISCUSSION}

\subsection{Properties of the calcined powder}

Table 1 shows the phases obtained at various calcination temperatures, detected using XRD. Single M-phase was obtained at over $1200^{\circ} \mathrm{C}$ for $0 \leqq \mathrm{x}<0.5$. At lower temperatures, or $x \geqq 0.5$, hematite $(H)$, LaFeO3 (Orthoferrite:O) and spinel ferrite (S) were detected besides the $\mathrm{M}$ phase. At higher than $1250^{\circ} \mathrm{C}$, undesirable grain growth (over a few microns) occurred. After calcination at $1200^{\circ} \mathrm{C}$, almost all the primary particles were observed to

Table 1 Phases of the compounds Sr1-xLaxFe12-xZnxO19 calcined at various temperature for 1 hour in air.

\begin{tabular}{|c|c|c|c|}
\hline $\mathrm{X}$ & $1150^{\circ} \mathrm{C}$ & $1200^{\circ} \mathrm{C}$ & $1250^{\circ} \mathrm{C}$ \\
\hline $0,0.1,0.2$ & $\mathrm{M}+\mathrm{H}$ & $\mathrm{M}$ & $\mathrm{M}$ \\
\hline $0.3,0.4$ & $\mathrm{M}+\mathrm{H}+\mathrm{S}+\mathrm{O}$ & $\mathrm{M}$ & $\mathrm{M}$ \\
\hline 0.5 & $\mathrm{M}+\mathrm{H}+\mathrm{S}+\mathrm{O}$ & $\mathrm{M}+\mathrm{H}+\mathrm{O}$ & $\mathrm{M}+(\mathrm{H})$ trace \\
\hline over 0.6 & $\mathrm{M}+\mathrm{H}+\mathrm{S}+\mathrm{O}$ & $\mathrm{M}+\mathrm{H}+\mathrm{S}+\mathrm{O}$ & $\mathrm{M}+\mathrm{H}+\mathrm{S}+\mathrm{O}$ \\
\hline
\end{tabular}

$\mathrm{H}$ : hematite, $\mathrm{O}: \mathrm{LaFeO}_{3}$ (Ortho-ferrite), S: spinel ferrite 


\subsection{Fundamental properties of LaZn-substituted Sr-ferrite}

Up to a $4 \%$ increase of magnetization per mole $(\mathrm{NB})$ at room temperature was achieved, while the Curie temperature (Tc) and $H_{A}$ decreased monotonicaly as shown in fig. $1 . \mathrm{K} 1$ at $\mathrm{x}=0.3$ was $3.3 \times 10^{6} \mathrm{erg} / \mathrm{cc}$, the same as that of M-type Ba-ferrite. The increase of magnetization suggests $\mathrm{Zn}^{2+}$ substituted for $\mathrm{Fe}^{3+}$ at the $4 \mathrm{f} 1$ sites. The decrease of $\mathrm{Tc}$ and $\mathrm{HA}$ is explained by the substitution of non-magnetic ions $\left(\mathrm{Zn}^{2+}\right)$ for magnetic ions $\left(\mathrm{Fe}^{3+}\right.$ ). The lattice constant (c) decreased slightly, e.g. $23.05 \rightarrow$ $22.95 \AA$. This can be explained by the differences between the ionic radii of $\mathrm{La}^{3+}(1.17 \AA), \mathrm{Sr}^{2+}(1.32 \AA), \mathrm{Zn}^{2+}(0.74 \AA)$ and $\mathrm{Fe}^{3+}(0.79 \AA)$. X-ray density was calculated at around $5.20 \mathrm{~g} / \mathrm{cm}^{3}$ for $X=0.3$. Mossbauer spectra of ${ }^{57} \mathrm{Fe}$ had obviously changed but a decrease in intensity from $4 \mathrm{f1}$ sites was not established because of the ambiguity of fitting based on references [6-7].

\subsection{Properties of anisotropic magnets}

Figure 2 shows the magnetic properties at the optimum sintering temperature giving highest $(\mathrm{BH}) \max$ value. $4 \pi \mathrm{Is}, \mathrm{Br}$ and $\mathrm{Hk} / \mathrm{HcJ}$ increased, while $\mathrm{HcJ}$ decreased. When sintered at $1220^{\circ} \mathrm{C}$, maximum values of $\mathrm{Br}$ and $(\mathrm{BH}) \max$ were obtained for the composition with $\mathrm{x}=0.3$, viz.,

$4 \pi \mathrm{Is}=4.70 \mathrm{kG}, \mathrm{Br}=4.60 \mathrm{kG}, \mathrm{HcB}=2.54 \mathrm{kOe}, \mathrm{HcJ}=2.62 \mathrm{kOe}, \mathrm{Hk} / \mathrm{HcJ}=94 \%$

$(\mathrm{BH})_{\max }=5.2 \mathrm{MGOe}, \Delta \mathrm{Br} / \mathrm{Br} / \Delta \mathrm{T}=-0.20 \% /{ }^{\circ} \mathrm{C}, \Delta \mathrm{HcJ} / \mathrm{HcJ} / \Delta \mathrm{T}=0.31 \% / \mathrm{C}$

The density of the sample was $5.06 \mathrm{~g} / \mathrm{cm}^{3}(97.3 \%)$. The mean diameter of the grains was around $0.8 \mu \mathrm{m}$ and a considerable number of over-micron sized grains, regarded as multi-domain grains, were observed by SEM (Fig.3). The critical diameter for single domain isolated particles is calculated as $0.97 \mu \mathrm{m}$ for $\mathrm{x}=0$ and $0.90 \mu \mathrm{m}$ for $\mathrm{x}=0.3$. Thus the low ratio of single domain grains, as well as the decrease of $\mathrm{HA}$ value, resulted in a decrease of $\mathrm{HcJ}$ value from $4 \mathrm{kOe}($ at $\mathrm{x}=0)$ to $2.6 \mathrm{kOe}(\mathrm{x}=0.3)$. The Hk/HcJ value suggests that $\mathrm{LaZn}$-substitution promotes the homogeneity of micro structure. According to TEM-EDS analysis, neither $\mathrm{La}$ nor $\mathrm{Zn}$ was found to have segregated at the grain boundaries.

\section{CONCLUSION}

A small amount of $\mathrm{La}$ and $\mathrm{Zn}$ substitution $(\mathrm{x}=0.3)$ was very effective in increasing saturation magnetization of M-type Sr-ferrite, while the decrease of magnetic anisotropy was within $10 \%$. By producing submicron particles and orienting them in a magnetic field, we succeeded in achieving outstanding magnet properties of $41 \mathrm{~kJ} / \mathrm{m}^{3}(5.2 \mathrm{MGOe})$.

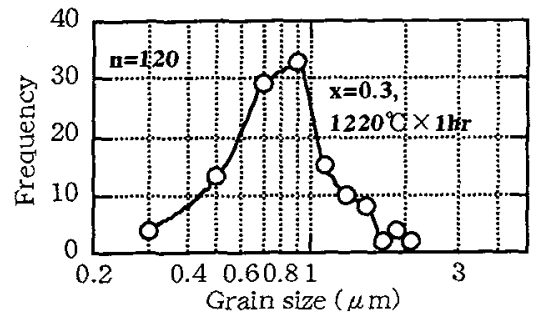

Figure 3: Grain size distribution of LaZn-substituted Sr-ferrite.

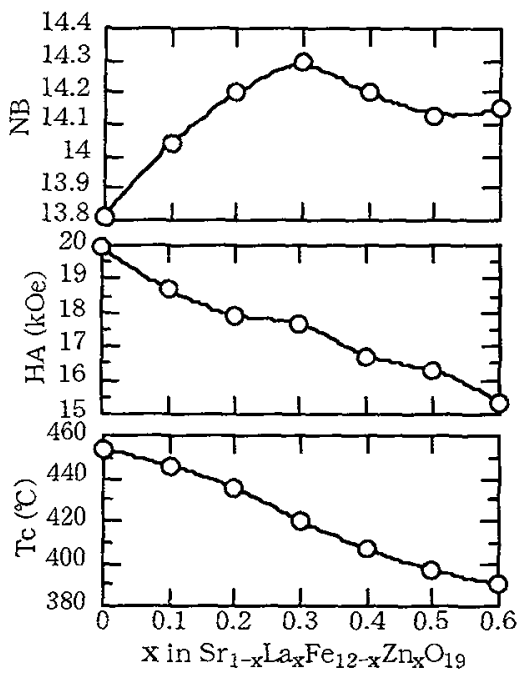

Figure 1: Dependence of magnetization (NB), anisotropic field $\left(\mathrm{H}_{\mathrm{A}}\right)$ and Curie temperature

(Tc) on the composition of substitution.
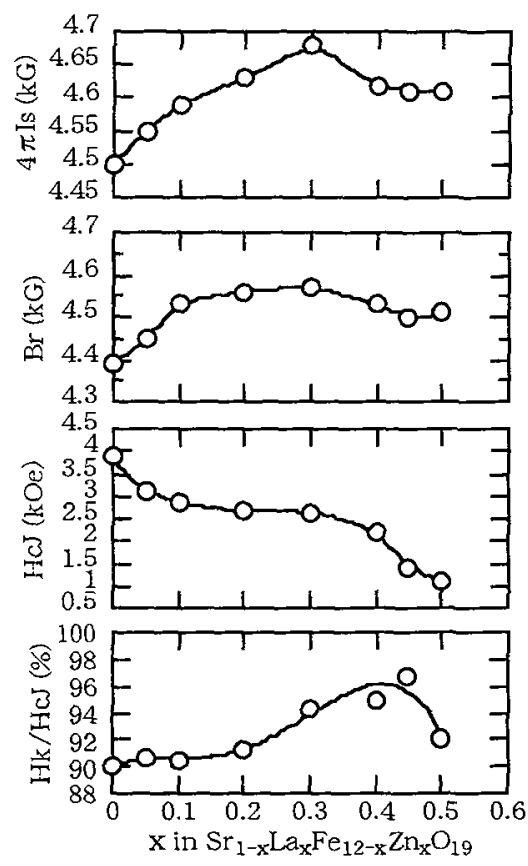

Figure 2: Magnetic properties of anisotropic ferrite magnets by substitution of $\mathrm{La}$ and $\mathrm{Zn}$.

\section{References}

[1] E.W.Gorter, Philips Res.Rep. 9 (1954) $403-443$

[2] Andre Deschamps and Felix Bertaut, Academie des Sciences 17 (1957) 3069-3072

[3] A.H.Mones and E.Banks, J.Phys.Chem.Solids 4 (1958) 217-222

[4] V.N.Mulay and A.P.B.Sinha, Indian J.Pure Appl.Phys 8 (1970) 412-415

[5] H.Taguchi, F.Hirata, T.Takeishi and T.Mori, "High Performance Ferrite Magnets", ICF6,Tokyo (1992), T.Yamaguchi and M.Abe Eds. pp.1118-1121

[6] G.K.Thompson and B.J.Evans, J.Appl.Phys. 67 (1990) 4601-4603

[7] S.Kulkarni,J.Shrotri, C.E.Deshpande and S.K.Date, J.Mater.Sci. 24 (1989) 3739-3744 